\title{
New Periodicals of 1962-Part II
}

\author{
By JAMES R. THRASH AND LUCIA P. JOHNSON
}

REFLECTING the currents and crises of the past twelve months, publications on outer space and Soviet Russia are prominent in the myriad of subjects found in this year's new magazines. Scientific journals abound, including publications on such specialized studies as biorheology, malacology, and topology. Cossacks, candy marketing, character potentials, and the crimes of Stalin also come in for treatment.

Americana. For the student of American culture in both its economic and cultural aspects, there are several new journals of interest. Journal of the West is a comprehensive illustrated magazine with articles in the first issue including "Scientists in New Spain: the Eighteenth Century Expeditions," and "The Branding Iron: the Cattleman's Coat-of-Arms." Another, but more specialized western journal is the Memoir of the Montana Archeological Society. For those with naval interests, American Steam Vessels Series will present drawings of Samuel Ward Stanton, the first number being devoted to Great Lakes steam vessels. For cultural history in the making, the Rural Vermonter will include in each issue such features as a calendar of events, Literary Vermont, and a Vermont personality.

ART, ARChItecture. A journal with a new angle is Environment. In terms of the fields of architecture, interior design, landscape architecture, painting, and sculpture, this magazine will explain the ways in which these professions can improve our home environment and our general environment. More traditional in their approach are Critica de Arte published by the Associação Brasileiro de Criticos de Arte and the Eastern Arts Quarterly which supplants the Art Education Bulletin as the official publication of the Eastern Arts Association. Art Voices from Around the World is an independent magazine of news, views, and opinions.

Bibliography, Libraries. In the field of bibliography, several new publications have appeared to aid the hard-pressed cataloger and researcher. Contemporary Authors will provide a quarterly bio-bibliographical guide to current authors and their works. Although major writers will not be neglected provided they are of current interest, emphasis will be upon new and relatively unknown authors who may be just coming into prominence. The second, third, and fourth volumes of each year will include a cumulative in-
Mr. Thrash became Editor of the Post1951 Imprints Section of the National Union Catalog in the fall of 1962. His work on this list, well started when he left the serials section of the descriptive cataloging division at the Library of Congress, was completed by Miss Johnson, Serials Cataloger at LC.

dex covering all entries for the year. In future years a separate index will be available which will cumulate entries from all volumes. A series similar to Dissertation Abstracts is the new Masters Abstracts. It will provide brief abstracts of selected masters' theses which are available as positive microfilm or as xerographic enlargements in book form. British Humanities Index, issued in London by the Library Association, supersedes in part the Subject Index to Periodicals. It will provide a current guide to articles in the humanities appearing in over 250 British periodicals and serve to complement the British Technology Index. From India comes the only new journal of library science. Herald of Library Science, sponsored by the Sarada Ranganathan Endowment for Library Science, is a quarterly organ for the library profession in India. Articles in the first issue include "Library Science during Renascence," by S. A. Ranganathan as well as others on local problems.

Business. In the field of general business and economics, the Montana Business Quarterly supersedes the Montana Business Review. It is hoped that it will contain more articles and cover a wider range of topics than the earlier magazine. Included in the price of the annual subscription will be a copy of each monograph published during the year by the Montana State University Bureau of Business and Economic Research. An addition to the field of operational research and scientific management will be Metra, published by the Metra Group, a "consortium" of scientific consulting companies in France, England, Germany, Italy, and Belgium. Papers will be published in English, French, German, or Italian. Two new publications are available for those interested in high finance. The Stock Market Magazine will offer articles spotlighting new outlets, new products, and new issues and highlighting significant developments in the security, mutual fund, and real estate markets, while Trendline's Current Market Perspectives will provide current and comparative 
financial and operating data, as well as a price chart, for each of 960 listed stocks. Those who are successful in the stock market can make use of Taxes Interpreted, issued by the Alexander Hamilton Institute in New York, which contains interpretive and informative material on current and forthcoming developments in the field of taxation. Two magazines designed to provide information on international trade and industry are Rassegna del Commercio Estero published primarily for the Italian businessman, and Industrial Intelligence published for British industry.

Colleges AND unIVErsities. With the rise of Harvard University's alumni to pre-eminence through their connections with certain echelons of the Democratic party, a magazine of opinion published at this institution takes on new significance. The Harvard Review, edited and published by the undergraduates, is in a sense a revival of the old Harvard Guardian. Each issue will be devoted to the exploration of a single topic of current interest, in as many dimensions and from as many perspectives as space permits. Topic for the first issue is the Atlantic Community. In addition, each number will contain special reports on study and research activities of the University's departments, graduate schools, and research centers. Rival Yale's students, with the generous support of alumnus Roger Blough, have produced a similar magazine, Yale Political. Like its Harvard counterpart, it treats only one subject in each number. In the first issue, devoted to the United Nations, the editors have amassed a formidable array of talent, including articles by such personages as Valerian Zorin, Soviet ambassador to the UN, Chester Bowles, senators Kenneth Keating of New York and Alexander Wiley of Wisconsin, and the late Dag Hammarskjöld.

With the publication of Under 30 , the Goldwaters of the university world have united. This publication presents the best articles from the two dozen conservative student magazines appearing regularly throughout the country and presents the resulting selection to a national audience.

Countries, areas. With Africa coming to the fore as one of the important areas of the world, numerous journals are making their appearance in this field. Africana Newsletter. Bulletin d'Informations Africana is published by the Hoover Institution to provide practical information for scholars and librarians on what reference works are being published on Africa south of the Sahara, on what agencies are collecting valuable Africana, and where African-related documents may be found in the United States, Europe, and Africa. The first issue describes the national archives of Nigeria, the German Foreign Minis- try archives, and the confidential prints of the British Foreign and Colonial offices, and American missionary archives. For information on Africa, itself, Burundi Chrétien, published under the authority of the archbishop of Kitega, is a newspaper containing articles on Burundi since its independence, as seen by the Catholic church. Published in Nairobi to serve as the journal of the East African Wild Life Society, Africana features in its first issue articles on the nine thousand-year-old trepanning operations of Kenya's Kissi, on what Livingstone called "the monstrous vegetable of Africa"-the baobab tree, and on the "yaller-dawg" of Africa, the Rhodesian ridgeback. A more general magazine on the warmer parts of the globe is Tropics which hopes to become a clearinghouse for information on these regions, focusing on such aspects as homes, living, and travel, as well as the pursuits of the culinary arts. Moving to colder regions, the Cossack Quarterly is published by the Cossack Nationalists in Exile. This publication is designed to promote the cause of national independence and be a source of information about the Cossack people.

Electronics. Symptomatic of the growing interest in data processing are two new journals. ICC Bulletin published by the International Computation Centre in Rome will include regular features on news of computing laboratories, new computers, forthcoming conferences, and training and education courses. Of special interest to the librarian will be the Information Processing Journal, an annotated index to the current literature on computers and data processing. Each issue will have detailed author and subject indexes which will be cumulated annually. Annotations will be arranged according to a general subject classification system.

Bandopname is the official organ of the Nederlandse Vereniging van Geluidsjagers. Published for those interested in tape recorders, this magazine deals in a popular way with the operational side of this field. A journal, customtailored to the interests of CBer's, persons operating private two-way radios on the so-called citizens band of frequencies assigned by the FCC for such uses, is 59; the Citizens Band Journal. In addition to articles on the description, construction, and use of various types of equipment it will also include articles on fundamental electronics. Frequency is a technical publication designed specifically for manufacturers, engineers, and scientists who "operate within a realm whose least common denominator is best defined by the utilization of frequency." Superseding Electronic Technology, and covering more on the practical applications of electronics and less on the theory, Industrial Electronics will feature information on new products in the industry. 
History. Soviet Studies in History, one of a series of new journals on Soviet Russia issued by International Arts and Sciences Press, will contain published articles selected primarily from nine Russian historical journals in unabridged English translation. Articles will be selected which best reflect developments in Soviet historiography. Slightly more sensational is the Bulletin d'Informations published by the Commission pour la Vérité sur les Crimes de Staline. The results of the investigations into the circumstances surrounding such events as the assassination of Trotski and Imre Nagy will be presented in this publication. The British Society for the History of Science has produced as its official organ, The British Journal for the History of Science. This magazine will contain scholarly papers as well as current information of the work of the society.

LANGUAGE. With as little specialization as possible, the Language Quarterly, published at the University of South Florida, hopes to have wide appeal for all teachers of linguistics and languages. The Journal of Verbal Learning and Verbal Behavior will offer articles dealing with laboratory studies on human learning as well as work in psycholinguistics and related disciplines. The main emphasis will be on experimental and empirical studies but theoretical papers with clear implications for current research will also be included. Published in London under the joint auspices of Michigan State University and the School of Oriental and African Studies of London University, the Journal of African Languages is an attempt to meet the growing need for a regular publication in this field.

LAw. Presenting recent ideas in the field of criminal law practice, the Criminal Law Quarterly is published jointly by the University of Southern California Law School and the Section on Criminal Law of the American Bar Association. The American Society of International Law has prepared an experimental number of a new publication International Legal Materials, which it hopes to develop into a current reporting service providing easy access to the basic source materials on the legal aspects of public and private international dealings. Following the pattern of the other journals on the Soviet Union published by International Arts and Sciences Press, Soviet Law and Government publishes articles selected from eight Russian legal journals in unabridged English translation. Of interest to any researcher on Argentina and its political system will be the Argentine Law Bulletin which will contain, in English, the complete texts of the principal laws, decrees, and resolutions as issued by the Argentine government. Each issue is indexed and a general index will accompany the sixth issue of each volume.
LITERATURE. Among the usual crop of literary magazines are a few of special interest. Unión, published in Havana, is the review of the Union de Escritores y Artistas de Cuba. El Corno Emplumado. The Plumed Horn, a magazine of poetry, prose, letters, and art from two hemispheres, in Spanish and English, describes itself as "a magazine whose pages conform to the word instead of whose words conform to pages." It seems likely that the contents will be "way out." In an attempt to provide a platform for the new generation of writers which has begun to emerge in Ireland, Oxford University Press is publishing The Dolmen Miscellany of Irish Writing. In an effort to preserve the old, The Jewish Mirror is designed to acquaint the American Jew with the Yiddish classics, in which are mirrored the life of the Jewish people. Magyar Mulhely is a literary and artistic review founded by the young Hungarian writers who have been living in Paris since 1956. Other literary journals include Genesis West, Pegasus, and Quartet. Nottingham French Studies is the only new journal of criticism. Directed to that section of the public which is interested in modern French literature, language, and general culture, the articles will be scholarly in content, but effort will be made to avoid the jargon and trappings of erudition. Papers will be published in English or French.

Man. Soviet Sociology and Soviet Anthropology and Archeology are two more in the series of journals published by the International Arts and Sciences Press. Each publishes articles selected from Russian journals in unabridged English translation. A periodical for the comprehension of the Jewish problem is Tribüne published in West Germany. It deals with the theological and cultural as well as the historical and political aspects of the problems which the Jewish people face. Of interest to librarians is the Index to Current Periodicals Received in the Library of the Royal Anthropological Institute. This library receives over four hundred current periodicals, covering all branches of the science of man and published in all parts of the world. The first regular issue will cover the first quarter of 1963.

MEDICINE. With more and more attention being focused on the new emerging nations, many of which are located in the tropics, the problems of this area have gained increasing importance. Dermatologia Tropica, official organ of the International Society of Tropical Dermatology, is concerned with the problems of tropical diseases which have for so long been a stumbling block to progress in these areas. Closer to the problems at home is Clinical Pediatrics which will present articles which apply to clinical problems encountered in office and 
nursing practice, community health situations, and the simpler hospital emergencies. Clinical Notes on Respiratory Diseases, published by the American Thoracic Society, the medical section of the National Tuberculosis Association, is financed by Christmas Seal contributions. In addition to original contributions, it will summarize from the world medical literature the latest developments that may be useful to the general practitioner.

Music. The Israel Music Institute, founded in 1961 by the National Arts Council, the Ministry of Education and Culture, and other public bodies, is charged with publishing original Israeli musical works in order to bring the best of Israel's music to the attention of musicians and music lovers all over the world. Its Bulletin lists musical works which have been approved for publication by the institute. It also provides biographical sketches of Israeli composers and includes articles on Israeli music. Folk songs, ballads, and tunes, as well as information on singers and new records will be included in the new journal Folk, published by the English Folk Dance and Song Society. Another English publication is Crescendo published specifically for professional jazz musicians and jazz bands. Discóbolo is a Spanish journal which apparently takes all music as its field. The first issue includes articles on Paul Anka, Eartha Kitt, the ballet today, the symphony as the masterpiece of Western music, and Spanish recording stars.

Occupations. Many new journals appeared in 1962 , devoting themselves to the interests of specialized businesses and industries. Food and Lodging Hospitality is designed to provide a total business reading service for motel, hotel, and resort executives and owners. Serving the volume candy buyers is The Candy Marketer which is concerned with the functions of buying, merchandising, and selling. In the building field, Contractor News is aimed at general contractors and special trade contractors engaged in contract building construction. It will present information on new product developments, new techniques of installation, new technology, and contractor interrelationships. From labor's point of view, Construction Craftsman, published by the Building and Construction Trades Department of the AFL-CIO, hopes to provide an overall view of union construction work and review the work in progress in the building trades. Another labor publication is the BoilermakersBlacksmiths Record, magazine of the International Brotherhood of Boilermakers, Iron Ship Builders, Blacksmiths, Forgers and Helpers.

Philosophy. Each issue of Pacific Philosophy Forum is unified formally by a common topic and a common structure. There is a thesis article and two counterthesis articles which under- take the development of a contrary position or develop other grounds for holding the same position as the thesis article. Finally there is an "assessment" article which comments upon both the thesis and counterthesis articles. Soviet Studies in Philosophy, another of the new publications being issued by Arts and Sciences Press, will publish articles selected from five Russian philosophical journals. The first issue of Cuestiones de Filosofía includes articles on Maurice Merleau-Ponty and Karl Jaspers.

Psychology. Soviet Psychology and Psychiatry, continues the pattern of the other Arts and Sciences Press publications on Russia, publishing articles taken from six Russian journals in these fields. The Edinburgh Psychological Review published by students in the psychology department of the University of Edinburgh is, according to its editors, the first Scottish student magazine to attempt a national circulation. The first issue includes articles on conditioning and perception, ionization as a factor in human behavior, and methods and terminology in time estimation studies. Issued by the Union College Character Research Project, Character Potential is meant for those engaged in religious and character education and will report on the major findings, research designs, and the philosophy of the project in its explorations of human potential.

RECREATION. From California, land of sunshine, come three new magazines devoted to outdoor living. SI; Surfing Illustrated is published to promote the sport of surfing and to raise it to the same status now enjoyed by skiing and sailing. Camping Illustrated is a magazine for all campers. Articles in the first issue cover a wide range of subjects and include "Washington: Camping to and from the Fair," "The Wild Boars of Apache Land," "Wisconsin: More Campsites This Year Than Ever," "When Your Youngster Wants a Gun," and "The Know-How of Back Packing." Whether it's to go camping or surfing, Scootourist will help you get there. It covers every aspect of scooters and "scootouring." The first issue includes articles on a "scootour" of Marin County, California, a history of the Vespa, descriptions of the Laverda and new Lambretta scooters, as well as information on summer scootering, travel off the beaten path, and an article on safety.

Religion. Catholicism has not only provided Time with its Man of the Year but has also provided the majority of the religious publications in this issue. Ramparts is a journal published and edited by Catholic laymen. It publishes fiction, poetry, art, criticism, and essays reflecting the positive principles of HellenicChristian tradition. Published by the Pallotine Fathers, Front Line is the quarterly of the So- 
ciety of the Catholic Apostolate, which has as its goal the bringing of the gospel to every creature. Articles in the first issue include "The General Council and the Laity" and "The Search for Humanism." In quite another area, The Catholic Market is devoted to the broad sphere of Catholic management and administrative interest. It will present coverage of trends and events in Catholic church, institutional, collegiate, and scholastic administration. The first issue includes a description of the bold architecture of St. John's Abbey Church, Collegeville, Minnesota, an article on church organs by Paul Hume, noted authority on church music, as well as articles on fund-raising, pension plans, automated vending, and food service facilities planning. Many readers who are not institutional administrators may find the magazine of interest. Unitas. Edición Española is the Spanish organ of the Asociacion Internacional Unitas. English, French, and Italian editions are also issued. It is devoted to the ecumenical movement.

Methodist History continues in part World Parish and is the first American periodical devoted entirely to Methodist history in the United States and other lands. Although basically popular in nature it contains some scholarly articles. The NSSA's Journal of Christian Education is the official organ of the National Sunday School Association's Commission on Research in Christian Education, superseding the commission's Research Reporter. It represents one of the more evangelical religious groups and the first issue includes articles on "Trends in Today's Sunday Schools," "A Biblical Philosophy of Christian Education," and "How is Christian Education Distinctive?" Jewish Tribune, published in London, is an organ of AngloJewish orthodoxy and will, according to its editors, represent the views of the Torah on any given matter.

ScIEnce. The American Mathematical Society is issuing Chinese Mathematics, a cover-to-cover translation of Acta Mathematica Sinica, published by the Academia Sinica Peking. The first issue translates v. 10, no. 1 (1960) of the Acta. Pergamon Press has issued a new international journal of mathematics, this one on Topology. Original and expository articles on the mathmatical and scientific theory of control and its applications and English translations of important foreign papers on control will be published in the Society for Industrial and Applied Mathematics. Journal. Series A: On Control. The Faculty of Science of the University of Tokyo in cooperation with the Physical Society of Japan and the Japan Society of Applied Physics is publishing the Japanese Journal of Applied Physics. It will include papers in English, French, or German covering applied physics and related fields, including those dealing with experimental techniques and instruments. Timeliness, brevity, and current importance of the subject matter will be of primary concern in the publication of Applied Physics Letters, new publication of the American Institute of Physics. In a related field, Pergamon Press is issuing a Journal of Quantitative Spectroscopy \& Radiative Transfer. In more restricted areas of science, the Institute of Malacology at Ann Arbor is publishing Malacologia, which is concerned with malacology, that branch of zoology which deals with mollusks. Ubiquitous Pergamon Press is also publishing the first journal devoted entirely to Biorheology, which comprises the study of deformation and flow of biological systems or of materials directly derived from living organisms. To help young people keep abreast of developments in all branches of the physical and natural sciences, the Association Canadienne-Française pour l'Avancement des Sciences is publishing Le Jeune Scientifique which supersedes Le Jeune Naturaliste.

SOCIAL, POLITICAL SCIENCE: From Germany and Colombia come new publications dealing with the state. Der Staat, published in the Western sector of Berlin, is a journal in which philosophers, theologians, lawyers, or political scientists may discuss, each from his own point of view, the state in idea and history, in law and reality. The structure and function of the state in a society in the process of change is the theme of Administración y Desarrollo, published in Bogotá by the Escuela Superior de Administración Pública. New publications dealing with the current world situation include Oost-West, published in The Hague, which is concerned with East-West relations and a publication devoted to Communist Affairs published by the Research Institute on Communist Strategy and Propaganda at the University of Southern California. Articles in the latter include "MoscowPeking Relations in Perspective" and "Khrushchev and Ulbricht on Berlin." Ismun Review is being published by the International Student Movement for the United Nations. The first issue includes articles on Dag Hammarskjöld, the British Commonwealth, and Basutoland.

SpAcE. The work of the staff of the Lunar and Planetary Laboratory of the University of Arizona on such subjects as lunar globe photography and systematic visual lunar observations will be reported in the laboratory's Communications, while the Information Bulletin for the Southern Hemisphere is being published to keep southern hemisphere astronomers abreast of what their colleagues are doing. Sterne und Weltraum, published in West Germany, is designed not for astronomers but for those interested in astronomy but lacking in the technical 
training of the professional. Its editors suggest that it might find a useful place in doctor's waiting rooms. Definitely not in the same vein is Space Science Reviews which will contain papers on scientific research carried out by means of rockets, rocket-propelled vehicles and also by means of stratospheric balloons and at observatories on the earth or moon. It is principally concerned with the pure scientific aspects of the subject, but instrumental and technical aspects will also receive attention. World Space Directory is a reference book of government agencies, major and component manufacturers, industrial representatives, colleges and universities, nonprofit research organizations, and publications in the missile/space industry. A special international section covers foreign countries. Finally, Icarus, published by Academic Press, is devoted to the new interdisciplinary science of the solar system which encompasses the fields of astronomy, geology, geophysics, meteorology, geochemistry, plasma physics, and biology as they relate to this area. Observational, experimental, and theoretical contributions bearing on the physics of interplanetary fields and particles, meteorology, geophysics, and cosmochemistry of all planetary bodies of the solar system (except Earth) as well as papers on astrodynamics and celestial mechanics which represent scientific rather than engineering contributions will also be included.

Technical abstracts. Soviet Inventions Illustrated supersedes the USSR Official Bulletin of Patents \& Inventions. Issued in three sections, Chemical, Electrical, and Mechanical \& General, it is available complete or by individual section. This publication provides detailed summaries in English, in most cases virtually complete translations together with drawings of the complete specifications for every new Russian patent within about six weeks of the first publication date in the U.S.S.R. The Nucleic Acids; an Annotated Bibliography of Current Literature indexes and annotates articles from approximately ninety journals.

Technology. The Journal of the British Nuclear Energy Society, which supersedes the Journal of the British Nuclear Energy Conference, contains original papers, information, and comment on developments in the nuclear field, and records of the discussions at the society's meetings. Materials Research is an international journal of the properties and testing of engineering materials. All articles will be published in English, but each paper will be abstracted in English, French, German, Italian, and Russian. Another journal concerned with testing materials is the Revista del IDIEM published by the Instituto de Investigaciones y Ensayes de Materiales of the University of Chile.
From November 1890 to December 1892 a Journal of the Sheffield Technical School Metallurgical Society was issued and now after a lapse of some sixty-nine years, during which the technical school has become a university, the Metallurgical Society is issuing a new Journal. This publication is designed as a more popular magazine published for the large number of people working in the restricted field of metallurgy who wish to keep in touch with developments elsewhere without having to plough through masses of original research or delve into a highly specialized review. Two new Russian publications are available in the field of technology. Russian Metallurgy and Fuels is a translated version of Izvestiia. Otdelenie Tekhnicheskikh Nauk. Metallurgiia $i$ Toplivo of the Akademiia Nauk SSSR, and covers the results of recent investigations at Soviet research institutes on the subjects of extraction metallurgy, ferrous and nonferrous metallurgy, and solid and liquid fuels. It contains complete translations of selected articles as well as illustrated digests or abstracts of the remaining text. $P e$ troleum: USSR is a translation of the Soviet journal Neftekhimiia. Power transmissions and the field of gears and drives are covered in Die Antriebstechnik published quarterly in Wiesbaden. Each article includes summaries in English and French.

Coming at the height of the controversy over pesticides aroused by Rachel Carson's Silent Spring, the World Review of Pest Control should be of more than ordinary interest. This magazine will present information on the place of the modern pesticide in the maintenance of public health, in crop and animal husbandry, and in the protection of material; on the research, both state- and industry-aided, from which these developments spring; and on the steps taken to safeguard the public from misuse and the consequent hazards.

Theater, Films. There appears to be a "new wave" of periodicals on motion pictures and the theater in 1962. Two magazines of film criticism are The Seventh Art, published from New York containing reviews of primarily foreign films; and Movie, published in London containing reviews of primarily Hollywood movies. Another London publication, Prompt, issued by the Dramatic Society of the University College, hopes to fill the gap between the popular theatrical magazines and the intellectually remote journals and to present "total theatre."

International Stage \& Film Review is an independent world-wide journal for promoters of television, film, and theater. It gives an over-all picture, as the editors state it, of "what is in the can, what is on the stage and screen, what is in projection, what is in the producer's mind." 


\section{Periodicals}

Administración y Desarrollo. Escuela Superior de Administración Pública, Bogotá, Colombia. no. 1, July 1962. Frequency not given. Price not given.

Africana. Eastern News Distributors, Inc., 225 Seventh Ave., New York 1. no. 1, Mar. 1962. Frequency not given. Price not given.

Africana Newsletter. Bulletin d'Informations Africana. The Hoover Institution, Stanford, Calif. v. 1, no. 1, Oct. 1962. Quarterly. $\$ 3.50$.

American Steam Vessels Series. Meriden Gravure Co., Meriden, Conn. [no.] 1, 1962. Frequency not given. Price not given.

Die Antriebstechnik. Peter Phillips, 141-09 Twenty-Eighth Ave., Flushing 54, New York. v. 1, no. 1, Apr. 1962. Quarterly. DM. 18,-.

Applied Physics Letters. Dept. S, American Institute of Physics, 335 E. 45th St., New York 17. v. 1, no. 1, Sept. 1, 1962. Monthly. $\$ 4.00$.

The Argentine Law Bulletin. Argentlaws Publishers, Gral. Enrique Martínez 1360, Buenos Aires. v. 1, no. 1, March 1962. Bimonthly. $\$ 20.00$.

Arizona. University. Lunar and Planetary Laboratory. Communications. Lunar and Planetary Laboratory, University of Arizona, Tucson. v. 1, no. 1-6, 1962. Frequency not given. Free to libraries.

Art Voices From Around the World. Art Voices Pub. Co., 200 E. 72nd St., New York 21. v. 1, no. 1, Oct. 1962. Monthly, except July \& Aug. $\$ 4.00$.

Bandopname. Scheldeplein 16, Amsterdam-10, Netherlands. Jan. 1962. Monthly. f 0,95 per issue.

The Begg Journal of Orthodontic Theory and Treatment. 205 E. Coolspring, Michigan City, Ind. v. 1 , no. 1 , July 1962 . Irregular. $\$ 5.00$.

Belgium; a Belgian Quarterly Review for Trade Expansion. 45, Avenue Legrand, Brussels 5. no. 1, 1962. Quarterly. \$2.00.

Biorheology. Subscription Dept., Pergamon Press, Ltd., 122 E. 55 th St., New York 22. v. 1, no. 1, July 1962. Quarterly. $\$ 30.00$.

Boilermakers-Blacksmiths Record. Publications Office, 592 New Brotherhood Building, Kansas City 1, Kan. v. 1, no. 1, July 1962. Monthly. $\$ 2.00$.

British Humanities Index. The Library Association, London. no. 1, Jan.-Mar. 1962. Quarterly? Price not given.

The British Journal for the History of Science. British Society for the History of Science, Ravensmead, Keston, Kent, England. v. 1, pt. 1 , no. 1, June 1962. Semiannual. $15 s$ per issue.

British Nuclear Energy Society. Journal. British Nuclear Energy Society, 1-7 Great George St., London SW1. v. 1, no. 1, Jan. 1962. Quarterly. $£^{3}$.
Burundi Chrétien. B.P. 232 Usumbura, Burundi. no. 1, July 1, 1962. Frequency not given. $60 \mathrm{fr}$. per 6 months.

Camping Illustrated. P.O. Box 2748, San Diego 12, Calif. v. 1, no. 1, July 1962. Monthly. $\$ 3.50$.

The Candy Marketer. Magazines for Industry, Inc., 660 Madison Ave., New York 21. v. 1, no 1, July 1962. Monthly. $\$ 2.00$.

The Catholic Market. Catholic Digest Publications, Inc., 44 E. 53d St., New York 22. v. 1, no. 1, Oct. 1962. Quarterly. \$3.00.

Character Potential. Union College Character Research Project, 10 Nott Terrace, Schenectady 8 , N.Y. v. 1, no. 1, Nov. 1962. Four numbers a year. $\$ 4.00$.

Chinese Mathematics. American Mathematical Society, 190 Hope St., Providence 6, R.I. v. 1, no. 1, 1962. Quarterly. \$17.50.

Clinical Notes on Respiratory Diseases. American Thoracic Society, 1790 Broadway, New York 19. v. 1, no. 1, Summer 1962. Quarterly. Free.

Clinical Pediatrics. 227-231 S. Sixth St., Philadelphia 5. v. 1, no. 1, Oct. 1962. Monthly. $\$ 10.00$.

Commission pour la Vérité sur les Crimes de Staline. Bulletin d'Informations. Mme. Altman, 6 rue d'Abbeville, Paris 10e. no. 1, May 1962. Quarterly. Price not given.

Communist Affairs. Research Institute on Communist Strategy and Propaganda, University of Southern California, University Park, Los Angeles 7. v. 1, no. 1, June 1962. Bimonthly. $\$ 5.00$.

Construction Craftsman. Building and Construction Trades Dept., AFL-CIO, 810 Rhode Island Ave. N.E., Washington 18, D.C. v. 1, June 1962. Monthly. \$3.00.

Contemporary Authors. Gale Research Co., The Book Tower, Detroit 26. v. 1, 1962. Quarterly. $\$ 28.50$.

Contractor News. Hagan Publications, Inc., 500 Bloomfield Ave., Montclair, N.J. v. 1, no. 1, Sept.-Oct. 1962. Frequency not given. Price not given.

El Corno Emplumado. The Plumed Horn. Anaxagoras 1345-4, Mexico 12, D.F. no. 1, Jan. 1962. Quarterly. \$3.00.

The Cossack Quarterly. P.O. Box 2460, Cleveland 12. v. 1, Winter 1962. Quarterly. Price not given.

Crescendo. 16 Gerrard St., London W1. v. 1, no. 1, July 1962. Monthly. $£ 1.16 s$.

Criminal Law Quarterly. University of Southern California Law School, University Park, Los Angeles 7. v. 1, no. 1, Nov. 1962. Quarterly. $\$ 6.00$.

Critica de Arte. Palacio da Cultura, 9.0 Andar- 
Sala 901, Rio de Janeiro. v. 1, no. 1, Dec. 1961-Mar. 1962. Frequency not given. Price not given.

Cuestiones de Filosofia. Acoyte 491 (5 piso, A) Buenos Aires. v. 1, no. 1, 1st quarter 1962. Quarterly. \$4.00.

Dermatologia Tropica. International Society of Tropical Dermatology, 870 Fifth Ave., New York 21. v. 1, no. 1, Apr. 1962. Quarterly. $\$ 8.00$.

Discóbolo. Sagasta, núm. 23, Madrid-4. v. 1, no. 1, Apr. 1962. Frequency not given. 130 pesetas.

The Dolmen Miscellany of Irish Writing. Oxford University Press, New York. no. 1, 1962. Irregular. Price not given.

Eastern Arts Quarterly. Mrs. Alicia Mock, Administrative Secretary, Eastern Arts Association, Kutztown State College, Kutztown, Pa. v. 1 , no. 1 , Sept.-Oct. 1962. Quarterly. $\$ 3.00$.

The Edinburgh Psychological Review. Mark P. Haggard, Psychology Department, University of Edinburgh, Edinburgh, Scotland. no. 1, May 1962. Frequency not given. Price not given.

Environment. 151 E. 50th St., New York 22. v. 1, no. 1, Autumn 1962. Quarterly. $\$ 10.00$.

Folk. E.F.D.S. Publications, Ltd., 80 New Bond St., London W1. no. 1, 1962. Frequency not given. $3 / 6$ per issue.

Food and Lodging Hospitality. 5 S. Wabash Ave., Chicago 3. v. 1, no. 1, Aug. 1962. Monthly. $\$ 3.00$.

Frequency. Frequency, Inc., 167 Corey Rd., Brookline 46, Mass. v. 1, no. 1, Nov.-Dec. 1962. Bimonthly. $\$ 7.00$.

Front Line. 309 N. Paca St., Baltimore 1. v. 1, no. 1, Summer 1962. Quarterly. $\$ 3.00$.

Genesis West. Chrysalis West Foundation, 711 Concord Way, Burlingame, Calif. v. 1, no. 1, Sept. 1962. Quarterly. $\$ 3.00$ per year.

The Harvard Review. Lowell House H-14, Harvard University, Cambridge 38, Mass. v. 1, no. 1, Fall 1962. 4 issues during academic year. $\$ 2.25$.

Herald of Library Science. C 1, Banaras Hindu University, Varanasi-5, India. v. 1, no. 1, Jan. 1962. Quarterly. $\$ 6.00$.

Hydrospace Buyers' Guide. Data Publications, 1808 Wisconsin Ave. N.W., Washington, D.C. v. 1 , no. 1 , Summer 1962. Semiannual. $\$ 10.00$ per issue.

ICC Bulletin. International Computation Centre, Palazzo degli Uffici, Zona dell'E.U.R., Rome. v. 1, no. 1, Apr. 1962. Frequency not given. $\$ 3.00$.

Icarus. Academic Press, Inc., 111 Fifth Ave., New York 3. v. 1, no. 1, May 1962. 6 no. a year. $\$ 18.00$.

Index to Current Periodicals Received in the Library of the Royal Anthropological Insti- tute. Royal Anthropological Institute, 21 Bedford Sq., London WC1. Specimen issue, Jan. Mar. 1962. Quarterly. $£^{2}$.

Industrial Electronics. Iliffe Electrical Publications, Ltd., Dorset House, Stamford St., London SE1. v. 1, no. 1, Oct. 1962. Monthly. $\$ 8.50$.

Industrial Intelligence. Envoy Journals Ltd., 67 Clerkenwell Road, London EC1. v. 1, no. 1, May 1962. Monthly. Price not given.

Information Bulletin for the Southern Hemisphere. J. Sahade, Editor, Observatorio Astronómico, La Plata, Argentina. no. 1, Mar. 1962. Semiannual. Price not given.

Information Processing Journal. Cambridge Communications Corporation, 238 Main St., Cambridge 42, Mass. v. 1, no. 1, 1962. Monthly. $\$ 50.00$ per year.

International Legal Materials. American Society of International Law, 2223 Massachusetts Ave. N.W., Washington 8, D.C. v. 1, no. 1, Aug. 1962. Frequency not given. Price not given.

International Stage \& Film Review. Lion Mail Ltd., 68 Mill Lane, London NW6. Feb. 1962. Monthly. $£^{3}$.

Ismun Review. G. Arnn, 345 E. 46th St., New York. v. 1, no. 1, Feb. 1962. Frequency not given. $\$ .25$ per issue.

Israel Music Institute. Bulletin. Israel Music Institute, 24 Pinkas St., Tel-Aviv. no. 1, Summer 1962. Frequency not given. Price not given.

Japanese Journal of Applied Physics. Publication Office, no. 342, Physics Building, Faculty of Science, University of Tokyo, Bunkyu-ku, Tokyo. v. 1, no. 1, July 1962. Monthly. $\$ 10.00$.

Le Jeune Scientifique. c.p. 391, Joliette, Qué., Canada. (Collège de Joliette). v. 1, no. 1, Nov. 1962. 8 no. a year between Oct. and May. $\$ 3.00$ (Canadian).

The Jewish Mirror. Fred Goldberg, 4609 N. Kedzie Ave., Chicago 25. v. 1, no. 1, Sept. 1962. Quarterly. \$5.00.

Jewish Tribune. 55 Amhurst Park, London N16. v. 1 , no. 1, Mar. 30, 1962. Fortnightly. $\$ 5.00$.

Journal de Mécanique. Gauthier-Villars \& Cie, 55 Quai des Grands-Augustins, Paris 6e. v. 1, no. 1, Mar. 1962. Frequency not given. $\$ 14.00$.

Journal of African Languages. Macmillan \& Co., Ltd., St. Martin's St., London WC2. v.1, pt. 1, 1962. Frequency not given. $\$ 5.00$.

Journal of Quantitative Spectroscopy \& Radiative Transfer. Pergamon Press, Ltd., Heading. ton Hill Hall, Oxford, England. v. 1, no. 1, Sept. 1961. Frequency not given. $\$ 20.00$.

Journal of the West. 1915 South Western Ave., Los Angeles 18. v. 1, no. 1, July 1962. Quarterly. $\$ 6.00$.

Journal of Verbal Learning and Verbal Behavior. Academic Press Inc., 111 Fifth Ave., 
New York 3. v. 1, no. 1, July 1962. Frequency not given. $\$ 15.00$.

Language Quarterly. Editor, Albert M. Gessman, University of South Florida, Tampa. v. 1, no. 1, Fall 1962. Quarterly. \$.65 per issue.

Leicester Chemical Review. Chemical Society, University of Leicester, Leicester, England. no. 1, 1962. Frequency not given. Price not given. Magyar Múhely. 5 rue Marie-Davy, Paris $14 \mathrm{e}$. v. 1 , no. 1 , May-June 1962. Bimonthly. $\$ 7.00$.

Malacologia. Institute of Malacology, Inc., 2415 South Circle Drive, Ann Arbor, Mich. v. 1, no. 1, Oct. 1962. Irregular. Price not given.

Masters Abstracts. University Microfilms, Inc., 313 N. First St., Ann Arbor, Mich. v. 1, no. 1, 1962. Frequency not given. Price not given.

Materials Research. Heywood \& Co., Ltd., Scientific Publications Dept., Carlton House, Great Queen St., London WC2. v. 1, no. 1, Apr. 1962. Quarterly. \$15.00.

Methodist History. Association of Methodist Historical Societies, Lake Junaluska, N.C. v. 1, no. 1, Oct. 1962. Quarterly. \$2.00.

Metra. Science in General Management, Ltd., Grosvenor House, High St., Croydon, England. v. 1, no. 1, 1962. Quarterly. Price not given.

Montana Archeological Society. Memoir. Montana Archeological Society, 415 Leslie, Helena. no. 1, May 1962. Frequency not given. $\$ 1.25$ per issue.

Montana Business Quarterly. Bureau of Business and Economic Research, School of Business Administration, Montana State University, Missoula. v. 1, no. 1, Fall 1962. Quarterly. $\$ 4.00$.

Movie. 3 Antrim Mansions, London NW3. no. 1, June 1962. Monthly. $\$ 6.00$.

NSSA's Journal of Christian Education. National Sunday School Association, 175 North Franklin St., Chicago 6. v. 1, no. 1, Fall 1962. Quarterly. Price not given.

Nottingham French Studies. Editor, Nottingham French Studies, The University, Nottingham, England. v. 1, no. 1, May 1962. Semiannual. 6 ser issue.

The Nucleic Acids; an Annotated Bibliography of Current Literature. Special Bibliographies, P.O. Box 25, Loma Linda, Calif. v. 1, pt. 1, Jan.-June 1962. Frequency not given. $\$ 7.00$.

Oost-West. Postbus 107, 's-Gravenhage, Netherlands. v. 1, no. 1, Mar.-Apr. 1962. Bimonthly. f 12,50 .

Pacific Philosophy Forum. University of the Pacific, Stockton 4, Calif. v. 1, no. 1, Sept. 1962. Quarterly. \$6.50.

Pakistan Commerce \& Industry. Federation of Pakistan Chambers of Commerce \& Industry, Bellasis St., Karachi. v. 1, no. 1, May 1962. Monthly. $\$ 9.00$.
Pegasus. Department of English, Ballantine Hall, Indiana University, Bloomington. v. 1, no. 1, Fall 1962. Semiannual. $\$ 1.00$.

Petroleum: USSR. Pergamon Press, Ltd., 112 E. 55 th St., New York 22. v. 1, no. 1, 1962. Quarterly. $\$ 85.00$.

Prompt. Prompt Magazine, The Dramatic Society, University College London Union, Gower St., London WC1. no. 1, Summer 1962. 3 no. a year. $\$ 1.50$.

Quartet. Editor, Quartet, 1619 Potomac Ave., Lafayette, Ind. no. 1, Fall 1962. Quarterly. $\$ 1.00$.

Ramparts. The Layman's Press, 1178 Chestnut St., Menlo Park, Calif. v. 1, no. 1, May 1962. 5 no. a year. $\$ 8.50$.

Rassegna del Commercio Estero. Ente Italiano per lo Sviluppo e il Coordinamento degli Scambi con l'Estero, via Fabio Filzi 2, Milan, Italy. v. 1, no. 1, Jan. 1962. Frequency not given. Price not given.

Revista del IDIEM. Plaza Ercilla 883. Casilla 1420. Santiago de Chile, v. 1, no. 1, Mar. 1962. Frequency not given. $\$ .80$ per issue.

Rhodesian Institution of Engineers. Proceedings. P.O. Box 1477, Salisbury, Southern Rhodesia. v. 1, no. 1, Sept. 1962. Bimonthly. 34d.

Rural Vermonter. Charlotte McCartney, East Thetford, Vt. v. 1, no. 1, Fall 1962. Bimonthly. $\$ 2.00$.

Russian Metallurgy and Fuels. Scientific Information Consultants, Ltd., 661 Finchley Rd., London NW2. no. 1, Jan.-Feb., 1962. Monthly. $\$ 68.00$.

SI; Surfing Illustrated. Walt Phillips Productions, P.O. Box 697, Hermosa Beach, Calif. v. 1, no. 1, Winter 1962. Quarterly. $\$ 2.50$.

S9; the Citizens Band Journal. 300 W. 43rd St., New York 36. v. 1, no. 1, July 1962. Monthly. $\$ 5.00$.

Scootourist. 703 Higate Dr., Daly City, Calif. v. 1, no. 1, Aug. 1962. Monthly. $\$ 3.00$.

The Seventh Art. Carey Publications, Inc., 311 East 50th St., New York. v. 1, no. 1, Winter 1963. Quarterly. \$2.00.

Sheffield, England. University. Metallurgical Society. Journal. Sheffield University Metallurgical Society, St. George's Sq., Sheffield, England. v. 1, 1962. Frequency not given. 5s per issue. Society for Industrial and Applied Mathematics. Journal. Series A: On Control. Business Manager, SIAM Publications, Box 7541, Philadelphia 1. v. 1 , no. 1,1962 . Irregular. $\$ 3.50$ per issue.

Soviet Anthropology and Archeology. International Arts and Sciences Press, 156 Fifth Ave., New York 10. v. 1, no. 1, Summer 1962. Quarterly. $\$ 35.00$.

Soviet Inventions Illustrated. Derwent Information Service, Rochdale House, Theobalds Rd., London WC1. v. 1, no. 1, June 1962. Month- 
ly. $\$ 60.00$ (complete), $\$ 35.00$ (one section only) per 6 months.

Soviet Law and Government. International Arts and Sciences Press, 156 Fifth Ave., New York 10. v. 1, no. 1, Summer 1962. 4 no. a year. $\$ 35.00$.

Soviet Psychology and Psychiatry. International Arts and Sciences Press, 156 Fifth Ave., New York 10. v. 1, no. 1, Fall 1962. Quarterly. $\$ 35.00$.

Soviet Sociology. International Arts and Sciences Press, 156 Fifth Ave., New York 10. v. 1, no. 1, Summer 1962. Quarterly. $\$ 35.00$.

Soviet Studies in History. International Arts and Sciences Press, 156 Fifth Ave., New York 10. v. 1, no. 1, Summer 1962. Quarterly. $\$ 35.00$.

Soviet Studies in Philosophy. International Arts and Sciences Press, 156 Fifth Ave., New York 10. v. 1, no. 1, Summer 1962. Quarterly. \$35.00.

Space Science Reviews. D. Reidel Pub. Co., P.O. Box 17, Dordrecht, Netherlands. v. 1, no. 1, June 1962. Quarterly. \$42.00.

Der Staat. Duncker \& Humblot, Geranienstrasse 2, Berlin-Lichterfelde, West Germany. v. 1, no. 1, 1962. Quarterly. DM. 32,-.

Sterne und Weltraum. Verlag Bibliographisches Institut, 6800 Mannheim 1, Postfach 311, West Germany. no. 1, 1962. Monthly. DM. 20,-.

The Stock Market Magazine. Wall Street Publishing Institute, Inc., 69 Warburton Ave., Yonkers, N.Y. v. 1, no. 1, Jan. 1962. 11 no. a year. $\$ 6.00$.

Taxes Interpreted. Alexander Hamilton Institute, 235 E. 42nd St., New York 17. v. 1, no. 1, July 16, 1962. Biweekly. Price not given.

Topology. Pergamon Press, Ltd., 122 East 55th St., New York 22. v. 1, Apr.-June 1962. 4 no. a year. $\$ 30.00$.
Trendline's Current Market Perspectives. Trendline Corp., 82 Beaver St., New York 5. v. 1, no. 1, Oct. 16, 1962. Monthly. \$72.00.

Tribüne. Tribüne Verlag, Köln-Mülheim, Wiener Platz 2, West Germany. v. 1, no. 1, 1962. Quarterly. DM. 28,--

Tropics. P.O. Box 435, Coconut Grove 33, Fla. v. 1, no. 1, June 1962. Bimonthly. $\$ 4.00$.

The U-T Lawyer. University of Tennessee College of Law, Knoxville. v. 1, no. 1, Fall 1962. Quarterly. Price not given.

Under 30. I.S.I., 629 Public Ledger Bldg., Philadelphia 6. v. 1, no. 1, July 1962. Semiannual. $\$ 1.00$.

Unión. Calles 17 y H, El Vedado, La Habana, Cuba. v. 1, no. 1, May-June 1962. Bimonthly. $\$ 1.00$ per issue.

Unitas. Edición Española. Libreria Urquinaona, Lauria 4, Barcelona 10. v. 1, no. 1, Jan.-Mar. 1962. Quarterly. \$2.00.

Ventures. Graduate School, Yale University, New Haven, Conn. v. 1, Winter 1962. Frequency not given. Price not given.

West Virginia Government. Bureau for Government Research, West Virginia University, Morgantown. v. 1, no. 1, Oct. 1962. Frequency not given. Free.

World Review of Pest Control. Publicity Manager, World Review of Pest Control, 43 Great Marlborough St., London W1. Quarterly. 5 guineas.

World Space Directory. Circulation Dept., American Aviation Publications, 1001 Vermont Ave. N.W., Washington 5, D.C. v. 1, no. 1, Fall 1962. Semiannual. $\$ 10.00$.

Yale Political. Circulation Director, 2138 Yale Station, New Haven, Conn. v. 1, no. 1, Feb. 1962. Quarterly. \$3.00.

\section{Bowdoin College Symposium}

SPEAKERS at Bowdoin College's symposium on "The Place of a Research Library in a Liberal Arts College" included Frederick Wagman, director of the University of Michigan library and president-elect of ALA; Eileen Thornton, librarian of Oberlin College; and Verner W. Clapp, president of the Council on Library Resources. The symposium was held on February 21-22, at Brunswick, Me.

Other speakers were Edward C. Kirkland, Athern P. Daggett, Richard B. Harwell, and Rex Warner, all of the Bowdoin faculty. Dr. Wagman's topic was "A University Librarian Views the Problems of the Liberal Arts College Library." Miss Thornton's subject was "Research in a College Library," and Mr. Clapp spoke on "The Promise of Advanced Techniques of Librarianship."

Participants in the symposium included editors, writers, and representatives of some fifty institutions of higher learning invited to attend by Bowdoin President James S. Coles and Richard Harwell, Bowdoin librarian. 